\title{
Analysis of Moral Judgement by Using Reproductive System Case Dilemma In High School Students
}

\author{
Susi Susanti ${ }^{1}$, Widi Purwianing $\operatorname{sih}^{2}$ and Hernawati ${ }^{2}$ \\ ${ }^{1}$ Program Studi Pendidikan Biologi, Sekolah Pascasarjana Universitas Pendidikan Indonesia, \\ J1. Dr. Setiabudi No. 229, Bandung 40154, Indonesia \\ ${ }^{2}$ Departemen Pendidikan Biologi, Universitas Pendidikan Indonesia, \\ Jl. Dr. Setiabudi No. 229, Bandung 40154, Indonesia
}

\begin{abstract}
Moral violations are often committed by teenagers ranging from smoking, drinking alcohol, narcotics, and dating that often lead to free sex. Before the destruction of the younger generation, it is necessary efforts of various parties to prevent it. One of them is through learning biology material reproduction system using moral reasoning approach. The purpose of this study is to analyze the moral reasoning of high school students $X$ in Cilacap by using the dilemma of the case of the reproductive system. The sample in this study amounted to 30 students with purposive sampling technique. The analysis technique used in this research is descriptive. The instrument used in the form of questionnaire case dilemma consisting of five cases of cigarettes, alcohol, narcotics, dating, and abortion. Questionnaire and interview data were analyzed using criteria of level of moral reasoning adapted from Kohlberg. The results showed that all students were able to solve the problem of the dilemma of the reproductive system. As for the details, the cases of cigarettes, alcohol and narcotics are mostly students on stage 2-Indivialism, Instrumental Purpose, and exchange. The dilemma of the dating case is on stage 3-Mutual Interpersonal Expectations, Relationships, and Interpersonal Conformity. The dilemma of an abortion case is on Stage 6: The universal ethical principle. The reasoning level of a person is strongly influenced by the dilemma of the case at hand.
\end{abstract}

Keywords: Moral Reasoning Stage by Kohlberg, the dilemma of the case, the reproductive system

\section{Introduction}

Today we have entered the era of globalization and experienced rapid growth in the mid-20th century with the internet. The sophistication of cyberspace technology such as the internet in addition to presenting important information for its users, simultaneously also serve "counter discourse" in the form of dishonest websites (cyberporns) that can lead to moral degradation [9].

Moral violations are often act by teenagers in the form of juvenile delinquency. Cigarettes and alcohol are the beginning for drug use. Indonesia became the target of drug dealers from various circles in the world on the grounds that $60 \%$ of the population are children and adolescents. They are still unstable, have a high curiosity so want to try new things. Moreover beliefs of society are increasingly degenerated [12]. Another juvenile delinquency that became a problematic study is quite interesting is dating. In some adolescents, dating is also used to engage in sexual activity [5]. This happens not only because external factors are also internal factors. Internal factors are hormones. Changes in sex hormones in teenagers can lead to an overflow of sexual urges [1]. Uncontrollable sexual impulses will eventually lead to pregnancy. Unwanted pregnancies usually lead to abortion.

The relationship between alcohol, drugs, and sexual function is very complex [2]. The problem of moral violations as described can not be approached only from one aspect, because reproductive health is affected and influences social systems and is closely related to values, morals, religions and cultures. Thus there needs to be 
an integrated effort to address the issue of moral violations committed by adolescents. One of them through education.

Education in Indonesia is based on the curriculum. In the 2013 curriculum the revision states that in biology learning there are four KI (Core Competencies) to be achieved. KI includes KI-1 (spiritual attitude), KI-2 (social attitude), KI-3 (knowledge), KI-4 (skill). In this case the position of moral education and its integration in biological learning is an aspect that can not be ignored. Thus biology learning not only teaches cognitive concepts but also exercises reasoning in an effort to reduce the problem of knowing teenagers.

Reasoning is the most important and reliable way to gain moral knowledge [4]. Moral reasoning emphasizes the reason why an action is done, rather than just the meaning of an action. Based on the exposure, the researchers conducted research on moral reasoning using the dilemma of the reproductive system case using a reference from Kohlberg (1975). There are 3 levels, and each level there are 2 stages. These stages of moral development apply universally and in a certain order [6]. Table 1 shows the six stages of moral reasoning presented by Kohlberg (1975).

TABLE I: Moral Reasoning Stages

\begin{tabular}{|c|c|c|c|}
\hline \multicolumn{4}{|c|}{ Content of Stage } \\
\hline Level and Stage & What is Right & Reason for Doing Right & Social Perspective of Stage \\
\hline $\begin{array}{l}\text { Level I- } \\
\text { PRECONVENTION } \\
\text { AL } \\
\text { Stage } \\
\text { Heteronomous } \\
\text { Morality }\end{array}$ & $\begin{array}{l}\text { To avoid breaking rules baked by } \\
\text { punishment, obedience for its } \\
\text { own sake, and avoiding physical } \\
\text { damage to persons and property }\end{array}$ & $\begin{array}{l}\text { Avoidance of punishment, and } \\
\text { the superior power of } \\
\text { authorities }\end{array}$ & $\begin{array}{l}\text { Egocentric point of view. Doesn't } \\
\text { consider the interests o others or } \\
\text { recognize that their differ from the } \\
\text { actor's; doesn't relate two points of } \\
\text { view. Actions are considered } \\
\text { physically rather than in terms of } \\
\text { psychological interest of others. } \\
\text { Confusion of autority's perspective } \\
\text { with one's own. }\end{array}$ \\
\hline
\end{tabular}

Stage 2-Indivialism, Following rules only when $\mathrm{i}$ is to Instrumental someone's immediate interest; Purpose, and acting to meet one's own interests exchange
To serve one's own needs or interests in a world where you have to recognize that other people have their interests, too. fair, what's an equal exchange, a deal, an agreement

LEVEL II- Living up towhat is expected by CONVENTIONAL people close to you or what Stage 3-Mutual people generally expect of people Interpersonal Expectations, Relationships, and "Being good" is important and Interpersonal means keeping mutual Conformity realtionships, such as trust, loyalty, respect and gratitude.

\begin{tabular}{lrl}
\hline Stage & 4-Social & Fulfilling the actual duties to \\
Sytem & and & which you have agreed. Laws are \\
to be upheld except in extreme \\
cases where they conflict with \\
& other fixed social duties. Right is \\
& also contributing to society, the \\
& group or institution.
\end{tabular}

LEVEL III-POST Being aware that people hold a CONVENTIONAL OR PRINCIPLED

Stage 5- Social Contract or Utility and Individual Rights. contract. Some non relative values and rights like life and
To keep the institution goin as a whole, to avoid the break down in the system "if everyone did it", or the imperative of conscience to meet one's defined obligations (easily confused with stage 3 belief in rules and authority; see text). A sense of obligation to law because of one's social contract to make and abide by laws for the welfare of all and fo the protection of all people's rights. A felling of contractual commitment, feely entered upon, to family, friendship, trust, and work obligations.
Concrete individualistic perspective. Aware that everybody has his own interest to pursue and these conflict, so that right is relative (in the concrete individualistic sense)

Perspective of the individual in relationships with other individuals. Aware of shared feelings, agreements, and expectations which take primacy over individual interests. Relates points of view through the concrete golden rule, putting yourself in the other guy's shoes. Does not yet consider generalized system perspective. Differentiates societal point of view from interpersonal agreement or motives. Takes the point if view of the system that defines roles and rules. Considers individual realtions in terms of place in the system.

Prior-to-society perspective. Perspective for a rational individual awareof values and rights prior to social attachments and contracts. Integrates perspectives by formal mechanisms of agreement, contract, objective impartiallity, and due process. Considers moral and legal points of view; recognizes that they 


\begin{tabular}{|c|c|c|c|}
\hline & $\begin{array}{l}\text { liberty, however, must be upheld } \\
\text { in any society and regardless of } \\
\text { majority opinion. }\end{array}$ & $\begin{array}{l}\text { Concern that laws and duties be } \\
\text { based on raional calculation of } \\
\text { overall utility,'the greatest good } \\
\text { for the greatest number" }\end{array}$ & $\begin{array}{l}\text { sometimes conflict and finds it } \\
\text { difficult to integrate them. }\end{array}$ \\
\hline $\begin{array}{l}\text { Stage } \quad \text { 6-Universal } \\
\text { Ethical Principles }\end{array}$ & $\begin{array}{l}\text { Following self-chosen ethical } \\
\text { principles. } \\
\text { Particular laws or social } \\
\text { aagreements are usually valid } \\
\text { because they rest on such } \\
\text { prinsiples, one acts in accordance } \\
\text { with the principle. Principles are } \\
\text { universal principles of justice : } \\
\text { the equality of huma rights and } \\
\text { respect for the dignity of human } \\
\text { beings as individual persons. }\end{array}$ & $\begin{array}{l}\text { The belief as a rational person } \\
\text { in the validity of universal } \\
\text { moral principles, and a sense of } \\
\text { personal commitment to them. }\end{array}$ & $\begin{array}{l}\text { Perspective of a moral point of view } \\
\text { from which social arrangements } \\
\text { derive. Perspective is that of any } \\
\text { rational individual recognizing the } \\
\text { nature of morality or the fact that } \\
\text { persons are ends in themselves and } \\
\text { must be treated as such. }\end{array}$ \\
\hline
\end{tabular}

\section{Method}

This research belongs to a kind of descriptive research, a study that seeks to describe and interpret objects as they are [11]. This is in accordance with the purpose of research is to obtain information moral reasoning high school students in Cilacap by using the dilemma of the case of the reproductive system.

The subject was chosen by purposive sampling. There are 30 high school students of class XII MIPA with characteristics of 8 men, 22 women. Age range between 16-18 years. High school teenagers were chosen because they were considered capable of thinking abstractly and hypothesized [3].

The moral reasoning that became the focus of this study refers to the idea of Kohlberg (1975). Moral reasoning data is collected using a questionnaire of case dilemmas consisting of five cases of cigarettes, alcohol, narcotics, dating, and abortion. The data obtained were analyzed qualitatively.

\section{Result and Discussion}

The case dilemma questionnaire is given to students who have gained knowledge of the reproductive system. Then do interviews to students to strengthen and deepen student answers. The results of data collection using the reproduction system case dilemma can be seen in Fig. 1.

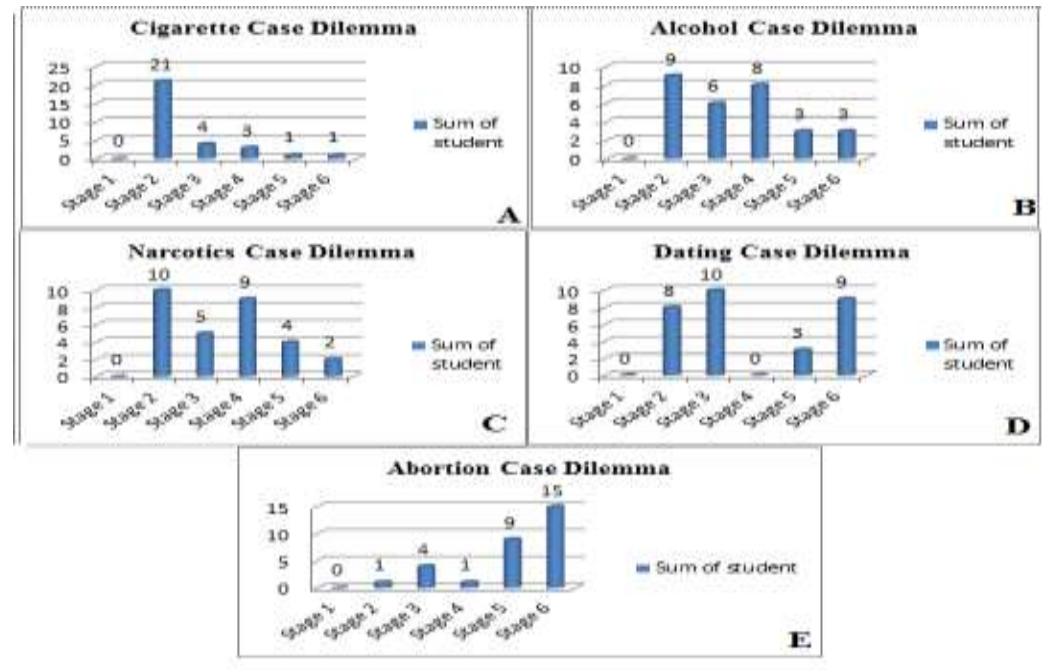

Fig. 1: Moral Judgment Student High School on reproductive System case dilemma

Explanation:

Stage I- Heteronomous Morality

Stage 2-Indivialism, Instrumental Purpose, and exchange

Stage 4-Social Sytem and Conscience

Stage 5- Social Contract or Utility and Individual Rights. 
Stage 6-Universal Ethical Principles

Based on Graph $1 \mathrm{~A}$ on the dilemma of cigarette cases it can be seen that the moral reasoning of high school students is mostly in stage 2. Graph $1 \mathrm{~B}$ on the dilemma of alcohol cases the highest level of moral reasoning is still the same as the dilemma of cigarette cases. But the distribution is more evenly distributed to higher moral levels. Graph $1 \mathrm{C}$ on the dilemma of the narcotics case is almost the same as the level of moral reasoning in the dilemma of alcohol case that is dominated by stage 2. Graph $1 \mathrm{D}$ about the dating dilemma experiences different levels of moral reasoning students are staged 3. Similarly Grafik $1 \mathrm{E}$ about the dilemma of abortion case experienced a significant difference that is half of the number of students are in stage 6 .

Based on graph 1 A.B.C.D.E. it can be seen that there are differences in the level of moral reasoning of high school students in the dilemma of the case of the reproductive system. In different cases the students' moral reasoning level will be different. Thus it can be said that the level of students' moral reasoning is strongly influenced by the dilemma of the case he faces. This is in accordance with the findings of Zeidler, Dana L. \& Schafer, Larry E. (1984) which states that moral reasoning is influenced by the context of moral dilemmas.

People tend to apply more sophisticated reasoning where they have a lot of interest, knowledge, or experience [13]. This is reinforced by the results of student interviews which states that the dilemma of the most dilemmatic case according to students is the case of abortion whereas the usual dilemma is the case of cigarettes. The reasoning used in resolving science-oriented moral dilemmas depends not only on general reasoning skills but also on attitudes, commitments and understandings. Based on this it can be disclosed that the more dilemma of a case then the more considerations presented. This is also apparent in student responses.

Case of Cigarettes:"I do not smoke to avoid the negative impact of cigarettes"

Case of Abortion: "It's better not to have an abortion. Because the abortion will cause extreme pain. In addition to endangering reproductive health, abortion can also claim lives if done illegally. The abortion is a sinful act, because having an abortion means killing life. Should avoid courtship and free sex "

The moral dilemma teaches students to make responsible decisions, where they learn to consider and assess all relevant factors, alternatives and risks before deciding on an action, and be responsible for their own choices and behaviors [5]. Dilemmas should be introduced into the field of moral education, using moral dilemmas as raw materials in moral education is a good way to improve students' moral judgment competence and can reveal their level of moral development [10]. Therefore, science teachers should strive not only to help students gain meaningful understanding of the subject matter, but also to try to help them develop positive attitudes, attention to science-oriented social issues, and commitment to solving actual problems [13]. In order for children to internalize values, they need to consistently see the values embodied by their teachers and other adult role models [7]. Thus teachers are required to behave as morally responsible professionals and act as role models for students [8].

\section{Conclusion}

Based on the results of research, the outline of high school students XII class has been able to solve the problem of the dilemma of the reproductive system. In the case of cigarettes, alcohol and narcotics most of the students are in Stage 2-Indivialism, Instrumental Purpose, and exchange, the courtship dating dilemmas are at the Stage 3-Mutual Interpersonal Expectations, Relationships, and Interpersonal Conformity stages. In the dilemma of abortion case is in Stage 6: The universal ethical principle orientation. Thus it can be concluded that the level of reasoning of a person is greatly influenced by the dilemma of the case at hand.

\section{Acknowledgements}

The researcher would like to thank Dr. Widi Purwianingsih, M.Si and Dr. Hernawati, S.PT., M.Si who has assisted in planning research proposal to prepare research and writing this article. The researcher also thanked 
Mr. Amin, S. Pd as the principal in SMA Negeri 2 Cilacap who has given permission to the researchers to perform test instruments and conduct research.

\section{References}

[1] Ahmadi, H.A. (1999). Psikologi Sosial. Jakarta : Rineka Cipta.

[2] Buffum, John. (1982). Pharmacosexology: The Effects of Drugs on Sexual Function - A Review. Journal of Psychoactive Drugs.[Online]. 14(1-2). pp. 5-44. Available: http://dx.doi.org/10.1080/02791072.1982.10471907

[3] Desmita. (2012). Psikologi perkembangan. Bandung: PT. Remaja Rosdakarya.

[4] Haidt, Jonathan. (2013). Moral psychology for the twenty-first century. Journal of Moral Education. .[Online]. 42 (3).. pp. 281-297. Available: http://dx.doi.org/10.1080/03057240.2013.817327

[5] Jersild, A.T., Brook, J.S., \& Brook, D.W. (1978). The Psychology of Adolescence. Third edition. New York : Mc Milan Publishing Co.

[6] Koh, Caroline . (2012). Moral development and student motivation in moral education: A Singapore study. Australian Journal of Education. [Online]. 56 (1). pp. 83-101. Available: http://research.acer.edu.au/aje/vol56/iss1/7/.

[7] Kohlberg, L. (1975). The Cognitive Developmental Approach to Moral Education. Phi Delta Kappa Internasional. [Online]. 56 (10). pp. 670-677. Available: http://www.jstor.org/stable/20298084

[8] Niekerk, Petro van. (2014). Teachers and Moral Development of Learners: A Case for a Kohlbergian and Neuroscience Approach. Mediterranean Journal of Social Sciences. [Online]. 5(4). pp. 340-347. Available: 10.5901/mjss.2014.v5n4p340

[9] Pillay, J. (2012). Keystone Life Orientation (LO) teachers: implications for educational, social, and cultural contexts. South African Journal of Education. [Online]. $30 \quad$ (2). pp. 167-177. Available: http://files.eric.ed.gov/fulltext/EJ1136318.pdf

[10] Samsuri \& Muchson. (2013). Dasar-dasar pendidikan moral (Basis Pengembangan Pendidikan Karakter). Yogyakarta: Penerbit ombak.

[11] Shaogang, Yang \& Huihong, Wu. (2008). The Features of Moral Judgment Competence among Chinese Adolescents. Asia Pacific Education Review. [Online]. 9 (3). pp. 296-307. Available: http://files.eric.ed.gov/fulltext/EJ835202.pdf.

[12] Sukardi. (2011). Metodologi Penelitian Pendidikan Kompetensi dan Praktiknya. Jakarta: PT Bumi Aksara.

[13] Willis, S. (2005). Remaja \& Masalahnya Mengupas Berbagai Bentuk Kenakalan Remaja Seperti Narkoba, Free sex dan Pemecahannya. Bandung: Alfabeta.

[14] Zeidler, Dana L. \& Schafer, Larry E. (1984). Identifying Mediating Factors Of Moral Reasoning In Science Education. Journal Of Research In Science Teaching. [Online]. 21(1). pp. 1-15. Available: doi: 10.1002/Tea.3660210102 